\title{
Critical Analysis of the Oversight Role of the Education Portfolio Committee in Parliament of South Africa
}

\author{
MANONA, W.W
}

\section{Abstract}

$\mathrm{T}$ here is a prevalent assumption in South Africa that Parliament is guided by the ideals of democracy, accountability, transparency and accessibility. However, there are still gaps and challenges as far as the oversight role of Parliament is concerned, despite the presence of committees that have been established to oversee the executive and relevant structures of government, government activities and public finances. There is widespread maladministration and misuse of government expenditure in government departments. This paper investigates the oversight role of parliamentary committees to determine their relative influence on accountability and democracy in the execution of functions by public functionaries.

The aim of the paper is to provide an understanding into inherent problems in the oversight role of Parliament in the democratic dispensation in South Africa, which seems not to have been given serious attention in the academia, considering the pivotal role
Parliament plays in the lives of citizens of the country. These oversight committees have selectively held Senior Executives or Ministers accountable for their ineffectiveness, misuse of government expenditure and maladministration. This could be attributed to the fact that oversight in South Africa does not seem to be properly understood and implemented as it should be. Moreover, the influence of the majoritarian authority of the ruling party in committees seems to be colluding with the executive. Failure to take action against cases of omission brings questions on the effectiveness and efficiency of the oversight role of Parliament. The adverse consequence is the delay in the provision of good quality services to poor communities. This paper employed the theoretical approach as a method of data collection. Conclusions have been drawn that the shortcomings of the parliamentary committees compromise accountability and good governance in service delivery.

Keywords: Parliament, Oversight Role, Accountability, Democracy, Government. 
Critical Analysis of the Oversight Role of Education Portfolio Committee in Parliament of RSA 73

\section{Background}

The true test of democracy is to the extent parliament ensure that government remains answerable to the people, which van Schalkwyk, Mmbadi and Jeewa argued is done through maintaining constant oversight of government's actions (van Schalkwyk, Mmbadi and Jeewa, 2014:4). Parliament and its committees have powers to summon any person or institution to give evidence or produce documents, and to report to them. According to sections 55 and 56 of the Constitution of the Republic of South Africa, Parliament has the power to conduct oversight of all organs of State, including those at provincial and local government level. In terms of the historical background of the evolution of oversight, Parliament's strategic vision is to build an effective people's Parliament that is responsive to the needs of the people, and that is driven by the ideal of realising a better quality of life for all the people of South Africa, and its mission is to represent and act as a voice of the people in fulfilling Parliament's constitutional functions of passing laws and overseeing executive actions. Based on the vision and mission of Parliament and the constitutional requirements, Parliament hereby develops mechanisms to guide its work on oversight, specifically in the form of an oversight model (van Schalkwyk et al., 2014:4).

Historically, the 1994 elections ushered in a new democratic order in South Africa. van Schalkwyk et al., (2014:4) contend that the extraordinary participation by South Africans showed that they desired an end to the divisions of the past and working toward establishing a society based on democratic values, social justice and fundamental human rights. The process of negotiations, which preceded the 1994 elections, resulted in the drafting of a new Constitution, as adopted on 8 May 1996 by the Constitutional Assembly. The mandate of Parliament is achieved through passing legislation, overseeing government action, facilitating public participation and international participation (van Schalkwyk et al., 2014:4). In line with the founding provisions of the Constitution (Act 108 1996), the role of Parliament includes the promotion of the values of human dignity, equality, non-racialism, non-sexism, the supremacy of the Constitution, universal adult suffrage and multi-party system of democratic government. It upholds citizens' political rights, the basic values and principles governing public administration, and oversees the implementation of constitutional imperatives.

Much of Parliament's focus in the first decade of democracy was on ensuring the transformation of South Africa's legislative landscape, in line with the country's first 
democratic Constitution, Act 108 of 1996. In this process, Parliament's oversight function received less attention, further compounded by the reality that the Constitution deals with Parliament's legislative authority in more detail, compared to its oversight role (van Schalkwyk et al., 2014:4). In giving credence to its increasing important oversight role, Parliament's new strategic vision, that is, to build an effective people's Parliament "... better quality of life for all the people of South Africa, underpinned the manner in which the organisation began engaging on the need to institutionalise public participation as an integral part of its oversight function (van Schalkwyk et al., 2014:4). The motivation for political delegations to undertake the management of the legislative and oversight programme of Parliament demands capacity, competence and collective action.

Oversight is the supervision of government activities and public finances by the Legislature. It is a controversial concept that causes much debate among scholars, government and civil society. According to Redpath, Lue-Dugmore \& Kagee (2006:2), it is difficult to ascribe a single meaning to the term oversight as it applies to Portfolio Committees and Select Committees. It also includes developing strategies for government departments, daily monitoring and evaluation. Oleszek (2010:4) states that oversight has two basic meanings according to the dictionary. Firstly, it denotes some form of legislative "supervision" or "watchfulness" of delegated authority to Executive branch entities and officials. Secondly, it implies a "failure to notice" something that is overlooked or inadvertently omitted.

Redpath, Lue-Dugmore \& Kagee (2006:2) point out that oversight covers a wide range of activities, including briefings, hearings, consideration of submissions, inspection of governmental documents ranging from strategic plans to Annual Reports and budgets, the approval or rejection of pending legislation, and the engagement of the public in all these activities. Harris (1980:9) refers to oversight as a review process, which suggests that oversight includes inquiries about policies that are or have been in effect, investigation of past administrative actions, and the calling of Executive Officers to account for their financial transactions. Thus, the meaning of oversight is continually evolving. This differentiation in meaning not only affects the general functioning of government activities and public finances in South Africa, but also influences perspectives on the adequacy and effectiveness of the practice of oversight in the South African Parliament. 
Understanding the role of Parliament and oversight has not been easy in South Africa. It took time before Members of Parliament (MP's) began to internalise the separation of powers and to expect the Executive to justify their decisions to Parliament and not the other way round. In fact, there was no independent and transparent Parliamentary oversight in South Africa before the first democratic elections of 1994 (Le Roux, Rupiya and Ngoma 2004:49). It is expected and required that the execution of the oversight system should revolve around a set of functions to be followed in order for it to be effective when practised. As oversight potential increases, it becomes easier to scrutinise and control the government and its activities, since controlling the government is a key component of democratic government. This contributes to a political system becoming more democratic in its functioning. In other words, oversight potential is a cause not a consequence of democratic qualities. The concept of oversight contains many aspects, which include political, administrative, financial, ethical, legal and strategic elements. The function of oversight is mandated by the Constitution, as previously indicated, to detect and prevent abuse. Moreover, oversight seeks to prevent arbitrary behaviour or illegal and unconstitutional conduct on the part of the government and public agencies.

The core of oversight function is to hold Executive arm of government accountable, and also to seek to remedy situations where the Executive has not performed according to its stated policies. This function includes monitoring the achievement of goals set by legislation and the government's own programmes. In the light of the above, oversight seeks to improve transparency in government, which is itself a condition of effective policy implementation.

The institutions of oversight have the potential to investigate complaints from government departments and present findings either to Parliament or to publish them on their websites to be available to the public as well. These institutions of oversight are guided by their mandates. The positive aspect however, is that they all share a common interest, which is to serve the people of the Republic of South Africa and remain responsible and accountable in this service. These institutions are established to assist and to bring the relevant information concerning government departments and their officials to the public. Democratic accountability requires Executive control and Parliamentary oversight, as well as inputs by civil society (Born and Leigh 2007). 


\section{Problem Statement}

In South Africa, Committees in Parliament have been established to oversee the executive, relevant structures of government, government activities and public finances. Nevertheless, these oversight committees have selectively held Senior Executives or Ministers accountable for their ineffectiveness, maladministration and misuse of government expenditure. This could be attributed to the fact that oversight in South Africa does not seem to be properly understood and implemented as it should be. Moreover, the influence of the majoritarian authority of the ruling party in committees seems to be colluding with the executive. There is widespread maladministration and misuse of government expenditure in government departments, particularly in the Department of Education. However, public officials and Ministers concerned are rarely called upon to account for this. In certain instances, the Public Service Commission, Public Protector, the Auditor-General, Standing Committee on Public Accounts (SCOPA) and other State Institutions Supporting Democracy have made recommendations to Parliament for actions to be taken against wrong-doers, but few cases have been acted upon. Failure to take action against cases of omission questions effectiveness and efficiency in the oversight role of Parliament, which in turn compromises good governance and democratic accountability in the Public Service. The adverse consequence is the delay in the provision of good quality services to poor communities and the realisation of good governance.

Below, this study seeks to bring to the fore the steps it is taking to achieve the intended objectives of its undertaking.

\section{Research Questions}

- Is oversight in South Africa properly understood and implemented?

- What are the challenges in oversight?

- How can oversight be improved?

\section{Research Objectives}

- To ascertain better understanding of oversight and its implementation.

- To ascertain oversight dynamics in oversight.

- To provide recommendations on the improvement of oversight. 
On the basis of the above objectives, the research design and methodology to achieve the aforementioned objectives is discussed below.

\section{Research Design and Methodology}

This investigation has adopted an exploratory theoretical and desktop research because it is practically not feasible to quantify the positive or negative 'spin-offs' of oversight from recipient communities. If the researcher would rely on officials' empirical information, this would invalidate the authenticity and reliability of the findings, hence the theoretical approach reliance of the scholarly work. In order to answer the research questions and thus arrive at the goal of the research, a theoretical research analysis was used. Each and every data collected in this research was analysed in order to address the research questions. Thus, an exploratory theoretical method of inquiry allowed the researcher to understand the theory behind oversight and its effectiveness. According to Fox \& Bayat (2013:30), exploration implies a large proportion of scientific management research is conducted to explore a topic or to provide a basic awareness of the topic. This approach is used when a researcher examines a new interest or when the subject of investigation itself is relatively new. A theory represents a mental view of a system of ideas or statements used as an explanation of a group of facts or phenomena such that, a theory forms the basis for a chain of reasoning, leading to an understanding or explanation of a phenomenon (Hannekom \& Thornhill, 1994:480. Arguing along similar lines, (Asmah-Andoh 92012:12) states that any scientific study depends on the theory to investigate and explain the phenomena being studied with the objective to develop new knowledge and influence practice.

A research design is based on a set of decisions taken regarding factors such as what topic is to be studied in which population and what research methods will be employed for that purpose (Babbie, 2013:116). Mouton and Marais (1996:32) point out that a research design is basically an organisation of methods and conditions to be used in the collection and analysis of data in way that will bring about the relevance to the research purpose. As such, the decisions taken regarding the manner, methods and strategies in which research will be conducted, so as to answer the research questions and the phenomenon in question, constitute a research design. Kothari (2004:31) is of the view that a research design is in fact the conceptual structure that covers the scope in which research is be carried out. Within itself, a research design comprises of the plan for the 
collection, measurement and analysis of data. Basically, the design provides the entire plan in which the researcher is going to follow starting from the writing of a hypothesis and its operational implications to the final analysis of data. Therefore, a research design can be said to be that phenomenon that addresses the planning of a scientific investigation and the formulation of strategy for finding out something (Babbie \& Mouton, 1998:72). In a nutshell, research design can be viewed as a plan according to which research participants or subject will be obtained and collect information from them (Welman, Kruger \& Mitchell, 2005:52). However, the definitions of research design can be unclear and vague at times (De Vos, 2002:137). This is due to the fact that the term research design has two connotations. The first being that the term refers to alternative logical arrangements to be selected such as experimental research designs, correlation research designs and others in that category. The other connotation deals with the designing of the study in broad. This entails all the decisions taken to plan the study and these decisions are not only about the overall type or the design to use but also about factors such as sampling, sources and procedures for collecting data, measurements issues and data analysis plans (Rubin \& Babbie in De Vos, 2002:138). In the light of the above, an exploratory and desktop theoretical research method was used in this study.

Research projects are bound to raise ethical considerations. This is especially true when research involves people directly, but it may also be the case if research is conducted entirely on documentary evidence (Fox \& Bayat, 2013:148). Arguing along similar lines, Welman et al., (2005:181) point out that ethical behaviour is important in research, as any other field of human activity. Certain ethical considerations, concerned with such matters as plagiarism and honesty in reporting of results, arise in all research, but additional issues arise when the research involves human subjects. In line with the above, the researcher has a moral and professional obligation to be ethical. In so doing, reporting from the various sources of information consulted during the research study was done with honesty without distorting the ideas of authors. All sources cited in the study have been acknowledged. 


\section{Conceptualisation of Oversight}

In the South African context, oversight is defined as a constitutionally mandated function of legislative organs of the State to scrutinise and oversee Executive action and any Organ of the State (Pelizzo, Stapenhurst and Olson 2006: 8). Lenos (2010: 3) defines oversight as a key feature of Executive and Legislative relations, in which the Executive branch owes to the Legislative branch certain obligations and information. On the other hand, Lenos (2010:3) explains oversight as a supervision of the actions of administration. Such supervision includes, but is not limited to hearings, summoning of Ministers, resolutions of enquiry, Special Inventory Committees, and confirmation processes. A number of explanations provided in the study suggest that oversight is part of the institutional design established to guarantee a certain degree of control against excessive executive power, which is a fundamental component of a democratic government.

For the purposes of the study, the following working definition of parliamentary oversight will be used: "the review, monitoring and supervision of government and public agencies, including the implementation of policy and legislation" (The Constitution of the Republic of South Africa, 1996 Act 108 of 1996). This definition focuses on the purpose and nature of oversight activities rather than on the procedural stages in which oversight activities take place. According to Yamamoto (2007:9-10), the key functions of parliamentary oversight are described as:

- To detect and prevent abuse, arbitrary behaviour, or illegal and unconstitutional conduct on the part of the Government and public agencies. At the core of this function is the protection of the rights and liberties of citizens.

- To hold the Government accountable with respect to how the money of taxpayers is used. Parliamentary oversight detects waste within the machinery of the Government and public agencies. Thus, it can improve efficiency, economy and effectiveness of government operations.

- To ensure that policies announced by the Government and authorised by Parliament are actually implemented. This function includes monitoring the achievement of goals as set by legislation, the programmes of the Government, and the ten tools of Parliamentary oversight. 
- To improve transparency of government operations and enhance the trust of the public in government, which is itself a condition of effective policy delivery.

Parliaments use various tools in performing the abovementioned functions. Some of these tools are stipulated in the constitutions of countries, but more commonly they are part of the rules that govern parliamentary procedures (such sets of rules are often called standing orders). In South Africa, when Parliament is exercising oversight, it focuses on the following areas:

- Implementation of laws.

- Application of budgets.

- Strict observance of laws of Parliament and the Constitution.

- Effective management of government departments (www.parliament.gov.za).

\section{Challenges of Parliamentary Oversight in South Africa}

Pelizo, Stapenhurst and Olson (2006) argue that effective parliamentary oversight is essential to the quality of a democracy. The executive, in carrying out its tasks through implementing legislation or policy, acquires considerable power, such as the ability to influence or determine the conduct of a person. In a constitutional democracy, the condition for exercising that power is that the administration or executive must be checked by being held accountable to an organ of government that is distinct from it. This notion is inherent in the concept of the separation of powers, which simultaneously provides for checks and balances on the exercise of executive power, making the executive more accountable to an elected legislature. Again, the study finds it challenging for parliamentary committees who have to practise oversight, while being composed of the majority of the ruling party. Where it becomes a challenge is when they have to hold senior members of the same organisation, or party, to be accountable. Without being unreasonable, it is clear that some of these Ministers are their comrades or even seniors, thus the study finds this a challenge to the practice of oversight in Parliament. For committee oversight to be relatively effective, it would be advisable to consider the rotation of the chairing of committees so that it does not become a preserve of the majority party as it is currently the practice. Moreover, reaching of decisions in these committees through voting should be reviewed and consensus in decision-making should be embraced in order to accommodate opposing views of the 
minority parties. This would significantly reduce the number of court cases which have become a trend when opposition parties pursue the litigation route when they are disgruntled that their views are not given the necessary consideration.

According to Corder, Jagwanth and Soltau (1999:4), effective and proper oversight of the executive thus requires Members of Parliament (MPs) and Members of the Executive to fully understand the constitutional justifications and rationale behind accountability in government, and the purpose they serve. Accountability and oversight can be at their most effective if they are recognised by those in power as the central organising principles of the South African Constitution. The oversight role is often seen as that of opposition parties alone, designed to police and expose maladministration and corruption. Such a view is limited and deficient. Oversight and accountability, however, help to ensure that the Executive implements laws in a way that is required by the Legislature and the dictates of the South African Constitution. The legislature is in this way able to keep control over the laws that it passes and to promote the constitutional values of accountability and good governance.

Thus, oversight must be seen as one of the central tenets of the South African democracy because through it the Legislature can ensure that the Executive is carrying out its mandate, it monitors the implementation of its legislative policy, and draws on these experiences for future law-making. Through oversight South Africa can ensure effective government. When seen in this light, the oversight functions of the Legislature complements rather than hampers the effective delivery of services with which the Executive is entrusted.

\section{Accountability as Deliberate Measure of Oversight}

The concept of accountability in this study refers to ethics and good governance. According to Dykstra (1939:1-25), the concept is often used synonymously with concepts such as responsibility, answerability, blameworthiness, liability, and other terms associated with the expectation of accountability. As an aspect of governance, accountability has been central to discussions related to problems in the public sector, non-profit organisations and private organisations. Tumushabe, Mushemeza, Tamale, Lukwayo, and Ssemakula (2010:19) define accountability as an acknowledgement and assumption of responsibility for actions, products, decisions and policies, including administration, governance and implementation within the scope of the role or 
employment position. Tumushabe et al., (2010:19) further explain accountability as encompassing the obligation to report, explain and to answer for consequences.

The study confirms that accountability on its own is said to be the hallmark of modern democratic governance. In other words, democracy remains outdated if those in power cannot be held accountable in public for their acts, omissions, decisions, expenditure or policies. Historically, the concept of accountability was closely linked to financial accounting. However, it has now moved far beyond this and has become a symbol of good governance in both the public and private sectors. It must be noted that the ultimate goal of oversight function of the Portfolio Committee on Education is to ensure that those entrusted with public money are held accountable in the manner in which tax payers' money is spent (www.parliament.gov.za).

\section{Oversight Committees in Parliament}

Committees are universally found in Parliaments across the world. According to Yamamoto (2007:15), a Parliamentary Committee is a group of parliamentarians appointed by one chamber or both to undertake certain tasks. Yamamoto (2007:26) argues that the scope of the activities of permanent committees is limited by the rules under which they are established. Working in Committees allows Parliament to increase the amount of work that can be done and ensure that issues can be debated in more detail than in plenary sessions. Moreover, Committees increase the level of participation of MPs in discussions and enables them to develop expertise and in-depth knowledge of the specific Committee's area of work. Furthermore, they provide a platform for the public to present views directly to MPs, something that is not possible in a plenary sitting of Parliament.

On the other hand, Committees usually have the authority to decide whether or not a hearing should be open to the public. Committees also provide an environment for Parliament to hear evidence and collect information related to the work of a specific committee. Committees are, in general, proportionally representative of the parties in Parliament. Aldons (1985:333-351) believes that Parliamentary Oversight Committees contribute to pursuing accountability of management in government. 


\section{The Definition of the Portfolio Committee on Education}

The Portfolio Committee on Education is one of the Committees found in the National Assembly (NA) and its members are appointed by their fellow members. This committee is comprised of two bodies namely, the Portfolio Committee on Basic Education as well as the Portfolio Committee on Higher Education. According to Chaka, Bhagwam and Govender (2010:13), each portfolio committee in Parliament has between 17 and 19 full members and several alternate members. As it is acceptable that members of Portfolio Committees serve on more than one Portfolio Committee, it is a fact that this could also harm the effectiveness and efficiency of the Committee system.

Chaka et al., (2010:14) further explain that each Portfolio Committee has to elect a Chairperson, whose role is to preside over meetings and to ensure free participation by all members regardless of the political party they represent. Furthermore, Chairpersons are also responsible for allowing access by the public to Portfolio Committee meetings. In fact, these Committees are allocated a secretary and/or co-ordinator, as well as a researcher to provide them with the necessary support. Most committees have their own researcher, but some committees share a researcher. Furthermore, this committee reports directly to Parliament.

\section{The Functions of the Porffolio Committee on Education}

According to Chaka et al., (2010:16), the functions of the Portfolio Committee on Education are the legislative function, the policy function, overseeing the Department of Basic Education and the Department of Higher Education and Training, and other statutory bodies, and addressing issues of concern.

\section{The Legislative Function}

According to Chaka et al., (2010:17), this function involves discussing and amending education Bills, following their introduction in the NA. A Bill could be introduced by the Minister, the Portfolio Committee or by an individual Member. The Cabinet then approves the Bill after it has been introduced by the Minister of Education before it goes to the Legislature. In other words, once a Bill has been introduced, it is referred to the Portfolio Committee for consideration. The Committee recommends whether or not the Bill should be approved (deliberated through a motion of desirability in the Committee itself), and whether it needs amendments. It could decide to invite public participation 
by means of written submissions and public hearings before it prepares its recommendations. Parliament can send a Bill back for further consideration by the Committee, if it is not satisfied.

In ordinary Bills not affecting provinces (Section 75 Bill), once a Section 75 Bill has been passed by the National Assembly (NA), it is referred to the National Council of Provinces (NCOP). If the NCOP amends the Bill or rejects it, it goes back to the Assembly that may pass the Bill again, with or without amendments, and send it for the President's assent. In other words, the Assembly can pass a Section 75 Bill even if the NCOP disagrees (www.parliament.gov.za). In ordinary Bills affecting provinces (Section 76 Bills), the NCOP and the NA both consider Section 76 Bills. If they cannot agree, the dispute is referred to the Mediation Committee. If the committee is unable to secure agreement on Section 76 Bills introduced by the NA within 30 days, the Bill may be passed by the NA with a with a two-thirds majority and sent to the President. If the committee cannot broker an agreement on Bills that have been introduced in the NCOP, the Bill lapses (www.parliament.gov.za). If approved by Parliament, the Bill becomes an Act and is sent to the President for assent. Once the President signs it, the Act becomes law. The President has the power to send legislation back to Parliament for further consideration if it does not meet the requirements of the Constitution. This also relates to Bills affecting provinces, which are also considered in the National Council of Provinces.

\section{The Policy Function}

This function is mainly dealing with, debating and reviewing policies. Since 1994, the Committee has considered numerous policies, some of which revolved around the following:

- Language in Education Policy (1997)

- Norms and Standards for School Funding (1998)

- White Paper 5 on Early Childhood Development (2001)

- White Paper 6 on Special Needs Education (2001)

- National Curriculum Statement (2002)

- National Policy on Religion and Education of 2003 (Chaka et al. 2010:19). 


\section{Overseeing the Departments of Education and Statutory Bodies}

This is another function of the Portfolio Committee on Education, which is meant to monitor and oversee the work of the Departments of Education, as well as related statutory bodies. According to Chaka et al., (2010:20), this function, however, is performed in a number of ways such as:

\section{Examining and debating strategic plans and budgets}

Strategic plans are usually drawn up for a five-year period, to list the strategic objectives for the period, as well as the performance measures for these objectives. These plans are presented to the Portfolio Committee for comment and discussion. The Committee will look at the education budget in relation to the strategic plans drawn up by the Departments of Education to ensure that the allocations are in line with the plans. For example, the Portfolio Committee can question the Department on increases or decreases in the budget and their extent in relation to items prioritised in the departmental strategic plans.

\section{Examining annual reports}

Once a year, the Education Portfolio Committee reviews Annual Reports of the Departments and Statutory Bodies. It examines how the Departments or Statutory Bodies went about implementing their programmes, as well as what was achieved and the challenges faced. Financial statements also tell how much money was available and how much was spent. Reasons for under-spending or over-spending are also explored.

\section{Site visits}

As part of its oversight function, this Committee sometimes conducts site visits. For example, the Committee has checked on various issues such as school infrastructure and school nutrition by visiting various schools. Information obtained through site visits is used when questioning the Departments of Education on specific matters.

\section{Addressing issues of public concerns}

This function is meant to bring together the Departments of Education and the public in order to discuss any matter of concern arising between the two stakeholders. For instance, the Portfolio Committee may hold debates or public hearings on anything that it considers to be of concern and relevant to the 
delivery of any aspect of education. In addressing issues of concern, the Portfolio Committee may invite various local, regional and international experts to share information. This helps Committee Members to make more informed decisions and to make better recommendations in the future. However, the public may participate in the work of the Education Portfolio Committee in various ways, such as attending meetings, making written submissions, attending public hearings as well as alerting constituency offices to a problem.

\section{Analysis of the Oversight Role of the Portfolio Committee on Education}

Mindful of the critical role of oversight by the Portfolio Committee of Education on the department officials, the point needs to be made that it does not guarantee effectiveness and efficiency. The critique of the oversight role of the Portfolio Committee focuses on its supervision or "watchfulness" of delegated authority to public officials of the Department of Education and the failure of the Portfolio Committee to notice something that is overlooked or inadvertently omitted. Mindful of the fact that there are numerous oversight mechanisms that committees utilise, this paper has confined itself in selected tools of oversight, which have been identified to have deficiencies or challenges.

\section{Policy and Legislative Function}

According to Chaka et al. (2007:8), legislative oversight is considered an important duty in the promotion and protection of public interest. This involves debating and reviewing policies and discussing and amending Education Bills. The Committee could decide to invite public participation by means of written submissions and public hearings before it propose its recommendations.

The author's observation has been that the public has rarely been invited to make written submission or participate in public hearings, except to those Bills that have contentious issues. When the public is invited, it is given short notice. The invitation is mainly in newspapers, which excludes the majority of the people who cannot afford to buy newspapers or are unable to read. As a consequence, only the elite groups of civil society are afforded the opportunity to participate in these public hearings. The elite groups represent their interests on the pretext that they represent the views of the 
broader communities. This state of affairs cannot be seen as meaningful participation of communities in the legislative process of the Portfolio Committee.

\section{Overseeing the Departments of Education and Statutory Bodies}

In overseeing the Departments of Education and Statutory Bodies, the Education Portfolio Committee examines and debates the strategic plans and the budget for the Department and the Statutory Bodies. The Committee interrogates the Education Budget in relation to the strategic plans drawn up by the Department to ensure that allocations are in line with the plans. It questions the Department on increases or decreases in the budget and their extent in relation to items prioritised in the Departmental Strategic Plans.

The problem with the Committee is that it does not go beyond asking whether the money was spent as budgeted to establish proper prioritisation in order to alleviate poverty. In most cases, interrogation of the Department of Education officials relates to whether the money was spent as appropriated, and does not focus on establishing whether it brought about changes in terms of improving the quality of lives for the targeted communities. In other words, the outcomes of the Departments' spending remain hidden from scrutiny by the community as the measurement of progress is not given serious attention.

\section{Examining Annual Reports}

Once a year, the Education Portfolio Committee reviews Annual Reports of the Departments and Statutory Bodies. It examines how the Department and Statutory Bodies went about implementing their programmes, what was achieved and the challenges faced. Financial statements also tell how much money was available and how much was spent. The Committee also holds public officials to account for underspending and over-spending. However, considering that Department officials and Statutory Bodies are skilled in compiling these reports and are familiar with the kinds of questions that are likely to be asked, authentic accountability regarding these reports becomes questionable as collation of data becomes a routine exercise that is done with expert knowledge. The Committee does not do follow-ups on concerns raised nor does it monitor officials of the Department and Statutory Bodies. As a result, the following year these officials brief Members of the Committee on their programmes for that 
particular year, which defeats the purpose of holding the Departments and Statutory Body officials to account.

\section{Site Visits}

As part of its oversight function, this Committee sometimes conducts site visits. For example, the Committee has checked on various issues such as school infrastructure and school nutrition by visiting various schools. Information obtained through site visits is used when questioning the Departments of Education on specific matters.

The problem however, is the fact that these site visits are rarely conducted and when the Committee visits the school, it is usually only when there is a crisis situation. In other words, site visits are often conducted in reaction to a problem that exists, instead of being done proactively. As a result, by the time the Committee visits a school, teachers would be made aware and Members of the Committee would find that stability has been restored, which is counterproductive to the good intention of conducting site visits.

\section{Calling of Executive Officers to account for financial transactions}

When there are allegations of misappropriation of funds or embezzlement of taxpayers' money by any of the public officials, the Accounting Officer is summoned to appear before the Committee to account for financial transactions. However, the Committee has selectively held Senior Executives or Ministers accountable for their ineffectiveness, maladministration and misuse of government expenditure. This could be attributed to the fact that oversight in South Africa does not seem to be properly understood and implemented as it should be. Moreover, the influence of the majoritarian authority of the ruling party in committees seems to be colluding with the executive. In certain instances, the Public Service Commission, Public Protector, the Auditor-General, Standing Committee on Public Accounts (SCOPA) and other State Institutions Supporting Democracy have made recommendations to Parliament for action to be taken against wrong doers, but few cases have been acted upon. Failure to take action against cases of omission could bring questions about the effectiveness and efficiency of the oversight role of the Committee, which compromises good governance and democratic accountability in the Public Service. The adverse consequence is the delay in the provision of good quality services to poor communities and the realisation of good governance. 


\section{Conclusion}

The journal article concludes that oversight is a critical instrument for Parliament to oversee the performance of departments, which focuses on promoting good governance. However, the implementation challenges confronting oversight compromise the existence of this instrument to support the mandate of Parliament. Among other challenges identified in this article include ineffective method of invitation of the public to policy and legislative function, challenges with overseeing the Departments of Education and Statutory Bodies, ineffectiveness in examining annual reports, site visits that are seldom or reactively conducted, and selective calling of Executive Officers to account for financial transactions. This means that proper solutions should be analysed and implemented towards oversight, hence the next section will provide recommendations.

\section{Recommendations}

One of the research objectives of the study was to provide recommendations against oversight challenges. Based on the study's findings, various recommendations can be made.

\section{Ineffective method of invitation of the public to policy and legislative function}

Considering that legislative oversight is considered an important duty in the promotion and protection of public interest, it is suggested that the Committee could decide to invite public participation within reasonable time by means of written submissions and public hearings before it propose its recommendations. Other forms of communication for invitation to participate in public hearings, such as radio and mass meetings at grassroots should be given serious consideration in order to reach out to the broader communities.

\section{Challenges in overseeing the Departments of Education and Statutory Bodies}

Considering the fact that the political and economic structures have moved from a white nationalist government to that of a democratic multi-party government, Parliament should undertake the responsibility of ensuring that the operation and management of government activities and public finances are effectively managed to redress past inequalities, injustices and oppression through the effective and efficient running of the Portfolio Committee on Education. This should involve review, monitoring and supervision of government and public agencies, including the implementation of policy 
and legislation. In pursuit of good governance, it becomes critically important to be able to measure the quality of governance. Governance in the Portfolio Committee on Education is about how the Departments and Statutory Bodies ensure that they are doing the right things in the right way for teachers and learners, in a timely, inclusive, open, honest and accountable manner. A wider meaning of governance is that it relates to the capacity of a nation to provide its citizens with the choice of representation and unhindered participation in decision-making. It is understandable that governance is the style of interaction between a government and its people.

\section{Ineffectiveness in examining annual reports}

The key functions of Parliamentary oversight should be to detect and prevent abuse, arbitrary behaviour or illegal and unconstitutional conduct on the part of the government, especially through the Portfolio Committee on Education. At the core of the Portfolio's functions should be the protection of the rights and liberties of citizens to hold the government accountable with respect to how the money of taxpayers is used. The reason to emphasise these functions is to ensure that Parliamentary oversight of the Portfolio Committee on Education detects waste within the machinery of the Departments of Education and Statutory Bodies. This should be done while bearing in mind that civil society has high hopes and expectations about the tangible benefits of democracy and the Education System in South Africa.

\section{Site visits seldom or reactively conducted}

It is advisable that the Committee should be proactive and conduct regular unexpected visits to schools besides reactive interventions during crisis situations. Regular unexpected visits to schools could be a deterrent to inept and lack of work ethic by public functionaries in the Ministry of Education and, would in turn, militate against maladministration and corrupt tendencies.

\section{Selective calling of Executive Officers to account for financial transactions}

When there are allegations of misappropriation of funds or embezzlement of taxpayers' money by any of the public officials, the Accounting Officer is summoned to appear before the Committee to account for financial transactions. However, the Committee has selectively held Senior Executives or Ministers accountable for their ineffectiveness, maladministration and misuse of government expenditure. This could be attributed to the fact that oversight in South Africa does not seem to be properly understood and 
implemented as it should be. Moreover, the influence of the majoritarian authority of the ruling party in committees seems to be colluding with the executive. In certain instances, the Public Service Commission, Public Protector, the Auditor-General, Standing Committee on Public Accounts (SCOPA) and other State Institutions Supporting Democracy have made recommendations to Parliament for action to be taken against wrong doers, but few cases have been acted upon. Failure to take action against cases of omission could bring questions about the effectiveness and efficiency of the oversight role of the Committee, which compromises good governance and democratic accountability in the Public Service. The adverse consequence is the delay in the provision of good quality services to poor communities and the realisation of good governance.

Considering that accountability is an acknowledgement and assumption of responsibility for actions, products, decisions and policies, including administration, governance and implementation within the scope of the role or employment position, the ultimate goal of the oversight function of the Portfolio Committee on Education is to ensure that those entrusted with public money are held accountable in the manner in which taxpayers' money is spent. Accountability in its broadest sense is an obligation to expose, explain and justify actions. Therefore, the requirement that the Executive must justify its policies and decisions to Parliament is only one mechanism for ensuring accountability. These requirements that officials should provide reasons for their decisions according to Section 33(2) of the Constitution of the Republic of South Africa, that freedom of information legislation should be drafted and that there should be a judicial review of administrative action, are all means of making the Executive accountable for the exercise of its powers. Moreover, the committee should be mindful of the need for Executive Officers compliance with the Financial Management of Parliament and Provincial Legislatures Act of 2009 and the Constitution, which should be enforced, upheld and protected. There is, in particular, a need for ethical leadership among public functionaries and politicians entrusted with State power and public resources. Parliament should explore best practices and share lessons of experience with other countries, particularly in decision-making in committee work. Values-based leadership by political representatives should involve decision-making in the committee work that is informed by values and principles such as honesty, public interest, people first, equality, the rule of law and constitutional supremacy. 


\section{List of References}

- Aldons M E. 1985. Classification of Parliamentary Committees. Australian Journal of Public Administration 44 (4): 381-392.

- Asmah-Andoh, K. 2012. Effective and Efficient Performance Management in Local Government, with reference to the Cacadu District Municipality. Unpublished Doctoral Thesis. Port Elizabeth: Nelson Mandela Metropolitan University.

- Babbie, E. 2013. The practice of social research. $13^{\text {th }}$ edition. Belmont: Cengage Learning.

- Babbie, E. \& Mouton, J. 1998. The practice of social research. Cape Town: Oxford University Press.

- $\quad$ Born H \& Leiigh I. 2007. Democratic Accountability of Intelligence Services. Geneva Centre for the Democratic Control of Armed Forces. Policy Paper No 19.

- Chaka T, Bhagwan N, \& Govender, R. 2010. Education Portfolio Committees and Public Participation. Issues in Education Policy Number 7, Centre for Education Policy Development.

- Corder, H, Jagwanth S \& Soltau F. 1999. Report on Parliamentary Oversight and Accountability. Faculty of Law, University of Cape Town.

- De Vos, A.S. (ed.) 2002. Research at grassroots: For the social sciences and human service professions. $2^{\text {nd }}$ edition. Pretoria: Van Schaik.

- Dykstra C A. 1939. The Quest for Responsibility. The American Political Science Review 33(1): 1-25.

- Harris J P. 1964. Congressional Control of Administration. Garden City. New York: Anchor Books.

- Fox, W. \& Bayat, M.S. 2013. A guide to managing research. Cape Town: Juta \& Co.

- Hanekom, S.X. and Thornhill, C. 1994. Public Administration in Contemporary Society: A South African Perspective. Revised edition. Halfway House: Southern Book Publishers (Pty) Ltd.

- Kothari, C.R. 2004. Research methodology: Methods and techniques. New Delhi: New Age International $(P)$ Limited Publishers. 
- Le Roux L, Rupiya M \& Ngoma N. 2004. Guarding the Guardians: Parliamentary Oversight and Civil-Military Relations. Institute for Security Studies. Pretoria, Republic of South Africa.

- Lenos L B. 2010. Legislative Oversight of the Executive Branch in Six Democracies in Latin America. A paper delivered at the Oxford-Princeton Global Leaders Workshop, Princeton, NJ. London: Pluto Press.

- Oleszek W J. 2010. Congressional Oversight: An Overview. Congressional Research Services. Parliament of the Republic of South Africa. Our Parliament Pocket Guide. Cape Town: Parliament of South Africa.

- Parliament of the Republic of South Africa. Oversight and Accountability Model: Assessing Parliament's Oversight Role in Enhancing Democracy. http:// [www.parliament.gov.za downloaded on 2015-09-10]

- Pelizzo R, Stapenhurst R \& Olson D. 2006. Parliamentary Oversight for Government Accountability: The International Bank for Reconstruction and Development/ the World Bank, Washington, USA.

- Redpath J, Lue-Dugmore, M, \& Kagee, H. 2006. Assessing the Functioning of Provincial Portfolio Committees (Safety \& Security) in the Free State, Northern Cape and North West Provinces. Open Society Foundation for South Africa.

- Republic of South Africa. 1996. Constitution of the Republic of South Africa, Act No. 108 of 1996. Pretoria: Government Printers. (Government Gazette 17678).

- Republic of South Africa. 2009. Financial Management of Parliament and Provincial Legislatures Act, 2009 (Act 10 of 20090.

- Tumushabe G, Mushemeza E, Tamale, LM, Lukwago D \& Ssemakula E. 2010. Monitoring and Assessing the Performance of Local Government Councils in Uganda. Background Methodology and Score Card. ACODE Policy Research Series, No. 31, 2010. Kampala.

- Van Schalkwyk J., Mmbadi L. \& Jeewa Y. 2014. Oversight and Accountability Model. "Asserting Parliament's Oversight Role in Enhancing Democracy". Policy Documents Parliament.

- Welman, C., Kruger, F. \& Mitchell, B. 2005. Research methodology. $3^{\text {rd }}$ Edition. Cape Town: Oxford University Press.

- Yamamoto H. 2007. Tools for Parliamentary Oversight: A Comparative Study of 88 National Parliaments. Inter-Parliamentary Union. Switzerland. 


\section{AUTHOR'S CONTACT:}

MANONA, W.W.

Senior Lecturer: Public \& Development Management Saldanha Military Academy

Faculty of Military Science

Stellenbosch University

Email: manonaw@ma2.sun.ac.za 